\author{
Jolanta Kulpińska \\ Uniwersytet Łódzki \\ Społeczna Akademia Nauk
}

\title{
JAN SZCZEPAŃSKI - WIZJONER I REALISTA
}

Z okazji Jubileuszu 50-lecia Instytutu Filozofii i Socjologii PAN opublikowano tom zawierający teksty publicystyczne wielu pracowników Instytutu. Znalazły się tam liczne teksty publicystyczne i popularyzatorskie Jana Szczepańskiego, zwłaszcza z okresu, kiedy był jego dyrektorem. Na szczególną uwagę zasługuje próba diagnozy z 1957 r. W tym głośnym tekście Jan Szczepański wskazuje na frustrację Polaków z powodu niespełnionych obietnic i oczekiwań, traktując te nastroje jako źródło buntu. Podobnie ocenia ruchy społeczne lat 80 ., zwracając uwagę na niespełnione obietnice ustrojowe. Pojawia się przekonanie, że w Polsce po obaleniu realnego socjalizmu będzie podobnie jak w Europie Zachodniej - lepiej, szybciej, więcej.

Drugim tekstem o podobnym charakterze diagnozy jest obszerna Polska wobec wyzwań przyszłości, opublikowana w powielaczowej formie przez Instytut Geografii UW w końcu lat 80. Jan Szczepański, oceniając zachodzące procesy społeczne, liczył na liberalizację ustroju, wiązał to m.in. z rolą Kościoła, zwłaszcza komentując wybór Jana Pawła II na papieża.

Wiele komentarzy, ocen z pozycji państwowca wskazuje na troskę Jana Szczepańskiego o kształt i rozwój państwa i społeczeństwa. Profesor dostrzega znaczenie deideologizacji systemu i stwierdza, że realny socjalizm nie zmienił ludzi, a to właśnie był (i jest) warunek sukcesu krytykowanego ustroju.

W 1993 r. pojawia się książka Polskie losy, która zawiera ocenę procesu transformacji. Wybrałam te trzy publikacje, ponieważ zawierają bardziej całościowy opis sytuacji politycznej i społecznej. Interesujących tekstów z tego zakresu jest wiele - aż do ostatniej książki Jana Szczepańskiego pt. Najważniejsze i najtrudniejsze z roku 2003. 
Francuski socjolog Alain Touraine w artykule zawartym w Księdze poświęconej Szczepańskiemu pisze, że bez ludzi środka (tak sytuuje Szczepańskiego w konflikcie społeczeństwa i władzy) nie byłby możliwy sukces bardziej radykalnych przedstawicieli opozycji demokratycznej. Profesor liczył na stopniowe zmiany, niezbyt dobrze oceniając sposób przeprowadzenia transformacji. Uważał, że brakuje jasnej wizji, programu działania, kadr, zdolnych realizować nowy program.

Jan Szczepański uważa, że nowa sytuacja nie jest „restauracją”, bo czas komunizmu to kilka pokoleń. Nie był to czas pusty (jak sugeruje przeskok od II do III republiki). Skutki społeczne i ich ocena są negatywne, ale warto pamiętać o pozytywach, bo w latach 1945-1989 zrealizowano wiele ważnych społecznie celów, m.in.: reformę rolną, industrializację, elektryfikację, edukację, bezpieczeństwo socjalne, ,skok cywilizacyjny”.

Nawet jeśli uznamy, że wynik nie był w pełni osiągnięty (o czym mówili socjologowie i Jan Szczepański), to był to pewien sukces. A jednak system został przez społeczeństwo odrzucony, z powodu niespełnionych obietnic i widocznej niesprawności, zwłaszcza gospodarki. Jan Szczepański uważał, że w życiu społecznym można wyróżnić dwie sfery: formalną, instytucjonalną i mikrospołeczną, nieformalną dotyczącą życia codziennego. To, co charakteryzowało czas PRL, to niespójność tych dwu sfer (nawet rozbieżność). Państwo przeciwstawiano społeczeństwu. W tym napięciu systemowym kryło się ostateczne odrzucenie realnego socjalizmu.

Jednakże nie zarysowano (tu słabość opozycji według J. Szczepańskiego) wizji nowego ładu. Spowoduje to przedłużenie okresu transformacji z wieloma objawami dezorganizacji. Profesor zwraca uwagę, że nowy ład to imitacja Zachodu w nadziei na szybki skok cywilizacyjny i modernizację. Tymczasem, obok próżni instytucjonalnej, nieuchronnej anomii (Szczepański nie używa tych terminów, bo pisze popularnie), nie jest jasne, czyje i jakie interesy są czy będą realizowane. Ta niejasność jest wzmocniona przez zjawisko hybrydyzacji zbiorowości, klas i warstw.

Niewątpliwą zaletą Losów polskich jest ocena realnego socjalizmu i wyzwań nowego ustroju, wskazanie na społeczną sytuację i interesy różnych segmentów społeczeństwa, pokazanie perspektyw i zagrożeń. Jan Szczepański pisze o tym w kategoriach zadań, wyzwań. Wie, że rozwiązania będą różnorodne i niespójne. Ciekawe, że nie dostrzega, nie zajmuje się podziałami, które tam wyraźnie obserwujemy po roku 2000. Sądzę, że dlatego, że widział zadania i pozytywny program rozwojowy, dlatego, że dystansował się od tych podziałów - krytycznie oceniał sanację, nie akceptował endecji, zachowywał swoją miarę troski o państwo i społeczeństwo. 